\title{
Potensi Ekstrak Bunga Telang (Clitoria ternatea) Sebagai Pencegah Acute Kidney Injury (AKI)
}

\author{
Ersalita Rahmadhani Pratiwi ${ }^{1}$, Sukma Oktavia Aulia Rahmandani ${ }^{2}$, \\ Achmad Rivaldy Ibrahim ${ }^{3}$, Isbandiyah ${ }^{4 *}$ \\ 1,2,3Pendidikan Dokter, Universitas Muhammadiyah Malang \\ ${ }^{4}$ Departemen Penyakit Dalam, Universitas Muhammadiyah Malang
}

\begin{abstract}
ABSTRAK
Bunga telang (Clitoria ternatea) merupakan tanaman merambat yang memiliki berbagai jenis warna seperti pink, biru muda, putih, dan ungu. Tanaman ini biasa digunakan sebagai pewarna makanan dan tanaman hias. Bunga telang memiliki potensi farmakologi antara lain sebagai antioksidan yang tinggi. Antioksidan bunga telang menunjukkan aktivitas yang jauh lebih tinggi dibanding bunga lainnya. Antioksidan merupakan suatu zat yang dapat mencegah terjadinya Acute Kidney Injury (AKI) yang saat ini angka kejadiannya semakin meningkat dan angka kematian akibat AKI mencapai 23,9\% pada orang dewasa dan 13,8\% pada anak-anak. Artikel ini bertujuan untuk mendiskusikan potensi ekstrak bunga telang (Clitoria ternatea) sebagai pencegah Acute Kidney Injury (AKI). Metode penelitan yang digunakan yaitu teknik penelusuran pustaka pada 20 artikel dari database Google Scholar. Hasil penelusuran pustaka menunjukkan bahwa bunga telang (Clitoria ternatea) memiliki senyawa antioksidan yang berpotensi mencegah terjadinya Acute Kidney Injury (AKI). Ekstrak bunga telang memiliki potensi untuk menurunkan kadar urea, serum kreatinin, mengurangi kadar malondialdehyde (MDA) dan meningkatkan tingkat glutathione, katalase dan superoksida dismutase (SOD). Adanya aktivitas antioksidan flavonoid dan tanin pada ekstrak bunga telang ditemukan memberikan efek nefroprotektif terhadap adanya paparan bahan toksik. Kesimpulan dari penelusuran pustaka ini adalah kandungan antioksidan yang terkandung dalam ekstrak bunga telang dapat menjadi alternatif yang baik sebagai nefroprotektor untuk mencegah terjadinya AKI.
\end{abstract}

Kata kunci: bunga telang (Clitoria ternatea); antioksidan; acute kidney injury; AKI

\begin{abstract}
Introduction: Butterfly pea (Clitoria ternatea) is a vine that has various colors such as pink, light blue, white, and purple. This plant is commonly used as a food coloring and ornamental plants. Butterfly pea has pharmacological potential, among others, as high antioxidants. The antioxidants of the butterfly pea show much higher activity than other flowers. Antioxidants are substances that can prevent the occurrence of Acute Kidney Injury (AKI), which is currently increasing in incidence and mortality due to AKI reaching $23.9 \%$ in adults and $13.8 \%$ in children. Aim of study: This article aims to discuss the potential of butterfly pea extract (Clitoria ternatea) as a preventative for Acute Kidney Injury (AKI). Method: The research method used is the literature search technique on 20 articles from the Google Scholar database. Results and Discussion: The results of the literature search show that the butterfly pea (Clitoria ternatea) has antioxidant compounds that have the potential to prevent the occurrence of acute kidney injury (AKI). Butterfly pea extract has the potential to reduce levels of urea, serum creatinine, reduce levels of malondialdehyde (MDA) and increase levels of glutathione, catalase, and superoxide dismutase (SOD). The antioxidant activity of flavonoids and tannins in butterfly pea extract was found to have a nephroprotective effect against exposure to toxic substances. Conclusion: The conclusion from this literature search is that the antioxidant content contained in butterfly pea extract can be a good alternative as a nephroprotector to prevent AKI.
\end{abstract}

Keywords: butterfly pea (Clitoria ternatea); antioxidant; acute kidney injury; AKI

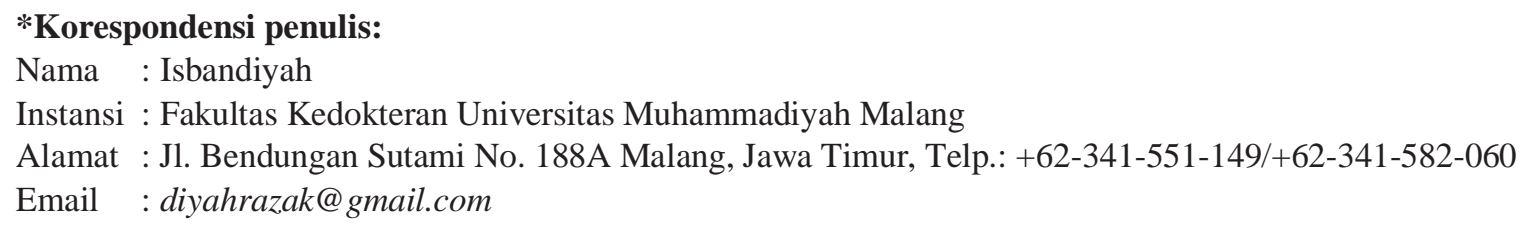




\section{Pendahuluan}

Ginjal memiliki peranan penting di tubuh manusia dalam mengekskresikan zat-zat beracun dan obat dari dalam tubuh, oleh sebab itu ginjal merupakan organ yang rentan terhadap kerusakan akibat stres oksidatif. ${ }^{1}$ Salah satunya penyakit yang diakibatkan stres oksidatif adalah acute kidney injury (AKI), yaitu suatu sindrom ditandai dengan fungsi ekskresi ginjal yang mengalami penurunan sehingga ginjal tidak mampu mencapai keseimbangan hidroelektrolitik secara efektif dan tidak mampu menjernihkan darah dari produk beracun dan produk-produk sisa metabolisme. ${ }^{2}$ AKI didefinisikan sebagai penurunan cepat dalam laju filtrasi glomerulus (GFR) yang mengakibatkan retensi limbah nitrogen, terutama kreatinin dan BUN. ${ }^{3}$

Kerusakan pada struktur ginjal, seperti tubulus, glomerulus, intertitium, dan pembuluh darah intrarenal dapat menyebabkan terjadinya $\mathrm{AKI}^{3}$ Untuk mencegah terjadinya kerusakan struktur ginjal yang akan mengakibatkan terjadinya AKI perlu suatu zat antioksidan. Zat antioksidan bekerja dengan cara meringankan cedera ginjal dan meningkatkan fungsi ginjal melalui pengurangan kerusakan oksidatif dan atau peradangan. ${ }^{4}$

Terapi yang dilakukan saat ini pada AKI hanya meliputi terapi nutrisi dan farmakologis seperti furosemid, manitol, dan dopamin. ${ }^{5}$ Obatobatan yang digunakan ini masih memiliki efek samping terhadap organ lain sehingga dengan adanya review ini diharapkan didapatkan ekstrak bahan alami yang mampu menjadi terapi alternatif pencegah AKI. Bunga telang yang sering dikenal masyarakat sebagai bunga biru dikenal memiliki beragam manfaat yang baik untuk meningkatkan kesehatan.

Bunga telang (Clitoria ternatea), dengan nama lain butterfly pea merupakan bunga yang khas dengan kelopak tunggal berwarna ungu. $^{6}$ Bunga telang merupakan tanaman jenis kacang-kacangan yang merambat serta tumbuh subur di bawah sinar matahari dan mudah untuk ditanam. ${ }^{7}$ Tanaman telang dikenali sebagai tumbuhan merambat yang sering ditemukan di pekarangan atau tepi persawahan atau perkebunan. Selain bunga ungu, bunga telang juga dapat ditemui dengan warna pink, biru muda dan putih. ${ }^{8}$

Selain sebagai tanaman hias, tumbuhan ini memiliki potensi farmakologi antara lain adalah sebagai antioksidan, antibakteri, anti inflamasi dan analgesik, antiparasit dan antisida, antidiabetes, anti-kanker, antihistamin, immunomodulator, dan potensi berperan dalam susunan saraf pusat. ${ }^{7}$ Bagian lain dari tanaman ini, yaitu daun dan akar juga memiliki potensi tersendiri. ${ }^{6}$ Aktivitas antioksidan dari ekstrak bunga telang menunjukkan aktivitas yang jauh lebih tinggi dibandingkan dengan bunga kertas dan bunga rosella. ${ }^{9,10,7}$ Selain itu, semakin meningkat konsentrasi ekstrak maka persentase ekstrak untuk menangkal radikal bebas juga meningkat. ${ }^{11}$

Tujuan penulisan artikel ini adalah menilai potensi ekstrak Clitoria ternatea sebagai antioksidan yang dapat mencegah terjadinya AKI. Artikel ini memiliki manfaat bagi masyarakat tentang terapi alternatif dengan menggunakan ekstrak Clitoria ternatea sebagai nefroprotektor alami dalam mencegah terjadinya AKI. Hasil penelusuran pustaka ini juga dapat dijadikan sebagai dasar penelitian selanjutnya tentang penggunaan ekstrak Clitoria ternatea terhadap perbaikan penyakit lainnya.

\section{Metode}

Metode yang digunakan dalam penulisan artikel ini adalah melalui teknik penelusuran pustaka pada 20 artikel dari database Google Scholar. Penelusuran Pustaka menggunakan beberapa kata kunci seperti butterfly pea (Clitoria ternatea), antioxidant; acute kidney injury, AKI. Teknik penelusuran Pustaka selanjutnya menggunakan sejumlah 20 artikel yang relevan dengan bahan kajian dan akan dikaji lebih lanjut dalam hasil dan pembahasan. 


\section{Hasil dan Pembahasan}

\section{Kandungan Bunga Telang \\ Fitokimia Bunga telang}

Bunga telang mengandung tanin, flobatanin, karbohidrat, saponin, triterpenoid, fenolmfavanoid, flavanol glikosida, protein, alkaloid, antrakuinon, antisianin, stigmasit 4ena-3,6 dion, minyak volatil dan steroid. Komposisi asam lemak meliputi asam palmitat, stearat, oleat lonoleat, dan linolenat. ${ }^{6}$ Kandungan tersebut sudah terbukti bahwa kandungannya menunjukkan banyak efek farmakologis termasuk antioksidan, hipolipidemik, antikanker, antiinflamasi, analgesik, antipiretik, antidiabetik, SSP, antimikroba, antiparasit gastrointestinal, insektisida, dan banyak efek farmakologis lainnya. ${ }^{12}$ Selain kandungan protein dan asam lemak, biji Clitoria ternatea juga mengandung asam p-hydroxycinnamic, $\beta$-sitosterol, $\gamma$ sitosterol adenosine, avonol-3-glycoside, ethyl$\alpha$-d-galactopyranoside, $\quad 3,5,7,4$ '-tetrahydroxy avone, 3-rhamnoglucoside, hexacosanol, dan anthoxanthin glukosida. ${ }^{13}$

\section{Efek Farmakologi}

\section{Antimikroba}

Ekstrak Clitoria ternatea dapat menghambat bakteri Pseudomonas aeruginosa, Escherichia coli, Klebsiella pneumonia, Bacillus subtilis, Aeromonas formicans, Aeromonas hydrophila dan Streptococcus agalactiae. ${ }^{12}$ Dari hasil pengujian laboratorium, ekstrak daun dan akar ditemukan paling efektif melawan terhadap semua organisme serta daun Clitoria ternatea menunjukkan aktivitas anti jamur paling efektif terhadap Aspergillus niger. ${ }^{12}$ Pengujian anti bakteri dilakukan pada daun dan akar Clitoria ternatea terhadap patogen. Hasilnya menunjukkan bahwa ekstrak daun menunjukkan aktivitas antibakteri yang lebih kuat dari pada ekstrak akar. Bunga telang memperlihatkan kemampuan dalam menghambat secara in vitro pertumbuhan biakan jamur Fusarium oxysporum. ${ }^{14}$

\section{Antioksidan}

Saat ini kebutuhan antioksidan alami diminati karena antioksidan sintetik memiliki efek samping misalnya alergi, asma, peradangan, sakit kepala, penurunan kesadaran, gangguan pada mata dan perut. ${ }^{15}$ Bunga Clitoria ternatea mengandung antioksidan. Hal tersebut terlihat dari warna mahkota karena mengandung antosianin. Antosianin merupakan pigmen dari flavonoid yang bersifat antioksidan. ${ }^{16}$

Studi terhadap aktivitas antioksidasi 15 jenis bunga menunjukkan bahwa ekstrak bunga telang merupakan salah satu dari bunga yang memiliki aktivitas antioksidasi paling tinggi. ${ }^{17}$ Dalam hal ini antosianin berperan sebagai agen antioksidan yang melindungi sel tanaman dari kerusakan akibat cahaya tinggi, melalui penyerapan sinar ultraviolet biru-hijau yang akan menghasilkan spesies oksigen reaktif yang disebut juga ROS. ${ }^{11}$

\section{Antidiabetes}

Beberapa penelitian telah dilakukan untuk meneliti dan menyelidiki potensi bunga telang yang dapat digunakan sebagai bahan alami untuk menurunkan kadar glukosa darah. Sebuah laporan oleh Gunjan et al. 2010 menyatakan bahwa kadar glukosa yang diuji pada tikus diabetes mengalami penurunan yang signifikan setelah 14 hari pemberian ekstrak bunga telang $150 \mathrm{mg} / \mathrm{kg}$ berat badan. ${ }^{18}$ Selain itu, pemberian ekstrak daun dan bunga telang pada tikus tersebut setelah disuntik aloksan mengakibatkan penurunan kadar glukosa serum, kolesterol total, trigliserida, urea, glukosa darah, hemoglobin terglikosilasi, dan kreatin secara signifikan sedangkan insulin serum, kolesterol HDL, protein, otot rangka dan tingkat kandungan glikogen meningkat. ${ }^{19}$ Selanjutnya, pada tikus yang diberi ekstrak bunga telang menunjukkan aktivitas antidiabetes positif terhadap hiperglikemik dan hiperlipidemia yang dapat mencegah kerusakan hati dan ginjal. ${ }^{11}$

\section{Hepatoprotektor}

Tikus yang diberi ekstrak Clitoria ternatea menunjukkan hasil yang positif dalam 
melindungi dirinya dari kerusakan akibat parasetamol. Menariknya, kelompok yang diobati dengan ekstrak Clitoria ternatea diamati memiliki tingkat enzim yang lebih rendah seperti aspartat aminotransferase (AST), alanine aminotransferase (ALT) dan bilirubin dibandingkan dengan peningkatan kadar AST, ALT, dan bilirubin pada kelompok yang diobati dengan parasetamol. ${ }^{20}$

\section{Acute Kidney Injury}

Acute Kidney Injury (AKI) adalah suatu sindrom ditandai dengan fungsi ekskresi ginjal yang mengalami penurunan. Ginjal menjadi tidak mampu mencapai keseimbangan hidroelektrolitik secara efektif dan tidak mampu menjernihkan darah dari produk beracun dan produk-produk sisa metabolisme. ${ }^{2}$ Selama 20 tahun terakhir tidak ada penurunan angka kematian yang drastis pada pasien - pasien yang menderita AKI. ${ }^{21}$ AKI lebih sering terjadi pada pasien dengan usia tua, pasien yang memiliki faktor predisposisi, pasien dengan tingkat komorbiditas yang lebih tinggi dan pasien yang memiliki kemungkinan lebih tinggi untuk mengembangkan penyakit yang parah. ${ }^{22}$

\section{Epidemiologi}

Beberapa laporan dunia menunjukkan insidens yang bervariasi antara $0,5-0,9 \%$ pada komunitas, $0,7-18 \%$ pada pasien yang dirawat di rumah sakit, hingga $20 \%$ pada pasien yang dirawat di unit perawatan intensif (ICU), dengan angka kematian yang dilaporkan dari seluruh dunia berkisar $25 \%$ hingga $80 \%$. Insidens di negara berkembang, khususnya di komunitas, sulit didapatkan karena tidak semua pasien AKI datang ke rumah sakit. Diperkirakan bahwa insidens nyata pada komunitas jauh melebihi angka yang tercatat. ${ }^{5}$

Pada penelitian terbaru menunjukkan bahwa, di dunia kejadian AKI di rumah sakit mendekati 1 dari setiap 5 orang dewasa, dan 1 dari setiap 3 anak. Kejadian AKI meningkat pada tiap tahunnya sebesar $10 \%$, sebagian karena pertumbuhan populasi dan peningkatan kejadian faktor pencetus AKI. Insiden dialisis karena AKI meningkat dengan kecepatan yang sama. Secara keseluruhan di seluruh dunia, AKI memiliki angka kematian $23,9 \%$ pada orang dewasa, dan $13,8 \%$ pada anak-anak. ${ }^{2}$

\section{Patofisiologi}

Dalam keadaan normal aliran darah ginjal dan laju filtrasi glomerolus relatif konstan yang diatur oleh suatu mekanisme yang disebut otoregulasi. Dua mekanisme yang berperan dalam autoregulasi yang pertama yaitu, reseptor regangan miogenik dalam otot polos vascular arteriol aferen dan timbal balik tubuloglomerular. Selain itu norepinefrin, angiotensin II, dan hormon lain juga dapat mempengaruhi autoregulasi. ${ }^{23}$

AKI dapat terjadi karena beberapa hal, terutama terkait dengan ketidaksesuaian antara oksigen dan pengiriman nutrisi (karena gangguan mikrosirkulasi) ke nefron dan peningkatan kebutuhan energi (karena stres seluler). AKI dapat digolongkan menjadi 3 golongan berdasarkan diagnosis yaitu pre-renal, renal, dan post-renal. ${ }^{24}$ Pada AKI pre-renal, hipoperfusi ginjal menyebabkan penurunan glomerular filtration rate (GFR) tanpa kerusakan pada parenkim ginjal, sebagai respons adaptif terhadap berbagai gangguan ekstraginjal. Diketahui bahwa mempertahankan GFR yang normal bergantung pada perfusi ginjal yang adekuat. Ginjal menerima hingga 25\% dari curah jantung dan dengan demikian setiap kegagalan dari volume darah yang bersirkulasi secara sistematis atau kegagalan sirkulasi intraginjal yang terisolasi dapat berdampak besar pada perfusi ginjal. ${ }^{24}$

AKI renal dapat menjadi tantangan untuk dievaluasi karena banyaknya variasi cedera yang dapat terjadi pada ginjal. Secara umum, empat struktur ginjal yang terlibat termasuk tubulus, glomeruli, interstitium, dan pembuluh darah intra-ginjal yang dapat dikategorikan sebagai AKI renal. ${ }^{24}$ Sedangkan AKI post-renal terjadi setelah obstruksi akut aliran urin, yang meningkatkan tekanan intratubular dan dengan demikian menurunkan GFR. ${ }^{3}$ Selain itu, obstruksi saluran kemih akut 
dapat menyebabkan gangguan aliran darah ginjal dan proses inflamasi yang juga berkontribusi pada penurunan GFR. AKI postrenal dapat berkembang jika obstruksi terletak di semua tingkat dalam sistem pengumpulan urin (dari tubulus ginjal ke uretra). ${ }^{24}$

\section{Terapi saat ini}

Pada dasarnya tatalaksana AKI sangat ditentukan oleh penyebab AKI dan pada tahap apa AKI ditemukan. Jika ditemukan pada tahap prarenal dan inisiasi (kriteria RIFLE R dan I), upaya yang dapat dilakukan adalah tatalaksana optimal penyakit dasar untuk mencegah pasien jatuh pada tahap AKI berikutnya. Upaya ini meliputi rehidrasi bila penyebab AKI adalah prarenal/hipovolemia, terapi sepsis, penghentian zat nefrotoksik, koreksi obstruksi post renal, dan menghindari penggunaan zat nefrotoksik. Pemantauan asupan dan pengeluaran cairan harus dilakukan secara rutin. Selama tahap poliuria (tahap pemeliharaan dan awal perbaikan), beberapa pasien dapat mengalami defisit cairan yang cukup berarti, sehingga pemantauan ketat serta pengaturan keseimbangan cairan dan elektrolit harus dilakukan secara cermat. Substitusi cairan harus diawasi secara ketat dengan pedoman volume urin yang diukur secara serial, serta elektrolit urin dan serum. ${ }^{5}$

\section{Potensi Bunga Telang Sebagai Nefroprotektor}

Ginjal memiliki peranan penting dalam sistem ekskresi manusia, oleh sebab itu ginjal merupakan organ yang rentan terhadap kerusakan akibat stres oksidatif melalui pembentukan molekul reactive oxygen species (ROS) yang dapat mencetus terjadinya kematian sel. Kerusakan yang terjadi pada ginjal dapat dideteksi dengan terjadinya peningkatan pada serum ureum dan kreatinin. ${ }^{25,26}$

Komposisi dalam bunga telang terbukti mengandung berbagai macam molekul bioaktif yaitu tanin, alkaloid, flavonoid, saponin, tanin, terpenoid, protein, antosianin, dan karbohidrat yang berfungsi sebagai antiepilepsi, anti inflamasi, anti oksidan, anti diabetes, antimikroba dan anti stres. Senyawa tersebut diketahui dapat digunakan sebagai pencegahan penyakit yang terkait dengan stres oksidatif. . $^{27,12}$

$$
\text { Banyak penelitian menunjukan }
$$
antioksidan dapat menghambat pencegahan berbagai jenis stres oksidatif. Mekanisme antioksidan dalam mengelola stres oksidatif dengan cara mengikat radikal bebas, penghambatan enzim oksidatif, mengikat ion logam, dan bertindak sebagai enzim kofaktor antioksidan. ${ }^{28}$ Pada penelitian sebelumnya telah dibuktikan bahwa pemberian ekstrak bunga telang pada tikus wistar dengan dosis 400 $\mathrm{mg} / \mathrm{kgBB}$ yang diinduksi aloksan dapat menurunkan urea dan serum kreatinin. ${ }^{19}$ Dan pada penelitian Somani et al, 2011 ekstrak daun bunga telang pada dosis $400 \mathrm{mg} / \mathrm{kgBB}$ terbukti secara signifikan mengurangi kadar malondialdehyde (MDA) dan meningkat tingkat glutathione, katalase dan superoksida dismutase (SOD). ${ }^{29}$

Kandungan antioksidan yang bekerja menghambat oksidasi bereaksi dengan radikal bebas reaktif sehingga membentuk radikal bebas tidak reaktif yang relatif lebih stabil sehingga dapat melindungi sel dari efek berbahaya radikal bebas oksigen reaktif. ${ }^{30}$ Antioksidan tersebut berperan penting dalam menghambat perubahan struktur maupun penurunan fungsional ginjal yang berakibat menjadi kerusakan ginjal. Aktivitas antioksidan flavonoid dan tanin yang terkandung pada ekstrak bunga telang dapat memberikan efek nefroprotektif dari paparan bahan toksik melalui mekanisme kerja yang berbeda. Flavonoid mengikat radikal bebas sehingga menstabilkannya dan dapat mengurangi radikal bebas. ${ }^{31,32}$ Tanin berkontribusi dalam mencegah terjadinya peroksidasi lipid dan menekan terjadinya ROS. ${ }^{33,34}$ Oleh karena itu, kandungan kaya akan antioksidan pada bunga telang dapat menjadi sumber alternatif alami sebagai nefroprotektor.

\section{Kesimpulan}

Stres oksidatif berperan penting dalam terjadinya penyakit ginjal, salah satunya dapat 
terjadi AKI. Banyak penelitian sebelumnya yang menyatakan bahwa kandungan antioksidan dapat mengoksidasi radikal bebas yang reaktif menjadi radikal bebas tidak reaktif. Sehingga berdasarkan penelitian sebelumnya didapatkan kandungan antioksidan pada Clitoria ternatea seperti tanin, alkaloid, flavonoid, saponin, tanin, terpenoid, protein, antosianin. Bunga telang diketahui juga memiliki kandungan antioksidan yang lebih tinggi dibanding dengan bunga lainnya.

Antioksidan berperan aktif dalam mengatasi stres oksidatif yang terjadi dengan cara mengikat radikal bebas, penghambatan enzim oksidatif, mengikat ion logam, dan bertindak sebagai enzim kofaktor antioksidan. Didukung oleh penelitian sebelumnya pemberian ekstrak bunga telang dapat menurunkan urea, serum kreatinin, mengurangi kadar malondialdehyde (MDA) dan meningkat tingkat glutathione, katalase dan superoksida dismutase (SOD). Sehingga, kandungan antioksidan yang terkandung dalam ekstrak bunga telang bisa menjadi alternatif yang baik sebagai nefroprotektor.

Dalam review ini memiliki keterbatasan dalam melakukan penelitian dikarenakan pandemi yang saat ini terjadi, sehingga peneliti tidak dapat melakukan penelitian lebih lanjut pada hewan coba. Diharapkan setelah adanya review mengenai ekstrak Clitoria ternatea sebagai pencegah AKI ini mampu dilakukan penelitian lebih lanjut pada hewan coba sehingga dapat diperoleh data lanjutan.

\section{Ucapan Terima Kasih}

Ucapan terima kasih kami sampaikan kepada Kemendikbud yang telah memberikan kesempatan kepada tim penulis dalam pendanaan PKM 5 bidang tahun 2020, khususnya skim PKM-PE.

\section{Referensi}

1. Verdiansah. Pemeriksaan Fungsi Ginjal. CDK-237 [Internet]. 2016 [cited 2020 July 20];42(2):148-154. Available from:
http://www.cdkjournal.com/index.php/CDK/ article/view/25.

2. M. Sancho-Martínez S, Prieto L, BlancoGozalo V, Fontecha-Barriuso M, VicenteVicente L, G. Casanova A, et al. Acute tubular necrosis: An old term in search for a new meaning within the evolving concept of acute kidney injury. European Journal of Molecular \& Clinical Medicine [Internet]. 2015 Jun [cited 2020 July 20];2(4-5):110. Available from: https://doi.org/10.1016/j.nhtm.2015.05.002.

3. Basile DP, Anderson MD, Sutton TA. Pathophysiology of acute kidney injury. Compr Physiol. [Internet]. 2012 Apr [cited 2020 July 20];2(2):1303-53. Available from: https://doi.org/10.1002/cphy.c110041.

4. Dennis JM, Witting PK. Protective Role for Antioxidants in Acute Kidney Disease. Nutrients [Internet]. 2017 Jul [cited 2020 July 20];9(7):718. Available from: https://doi.org/10.3390/nu9070718.

5. Sinto R, Nainggolan G. Acute Kidney Injury: Pendekatan Klinis dan Tata Laksana. Majelis Kedokteran Indonesia. 2010;60(2):81-88.

6. Budiasih KS. Kajian Potensi Farmakologis Bunga Telang (Clitoria ternatea). Prosiding Seminar Nasional Kimia UNY 2017 [Internet]. 2017 Oct [cited 2020 July 20]. Available from: http://seminar.uny.ac.id/semnaskimia/sites/s eminar.uny.ac.id.semnaskimia/files/2017/C7_Kun_Sri_Budiasih.pdf.

7. Palimbong S, Pariama AS. Potensi Ekstrak Bunga Telang (Clitoria ternatea Linn) sebagai Pewarna pada Produk Tape Ketan. J. Sains. Kes. [Internet]. 2020 Jun [cited 2020 July 20];2(3):228-35. Available from: https://jsk.farmasi.unmul.ac.id/index.php/jsk /article/view/147.

8. Kazuma K, Noda N, Suzuki M. Flavonoid composition related to petal color in different lines of Clitoria ternatea. Phytochemistry [Internet]. 2003 Nov [cited 2020 July 20];64(6):1133-9. Available from: https://doi.org/10.1016/s0031- 
9422(03)00504-1.

9. Djaeni M, Ariani N, Hidayat R, Utari, F. Ekstraksi Antosianin dari Kelopak Bunga Rosella (Hibiscus sabdariffa L.) Berbantu Ultrasonik: Tinjauan Aktivitas Antioksidan. Jurnal Aplikasi Teknologi Pangan [Internet]. 2017 [cited 2020 July 20];6(3):148-151. Available from: http://dx.doi.org/10.17728/jatp.236.

10. Haveni D, Mastura M, Sari RP. Ekstrak Etanol Bunga Kertas (Bougainvillea) Pink Sebagai Antioksidan Dengan Menggunakan Metode DPPH. Katalis: Jurnal Pendidikan Kimia dan Ilmu Kimia [Internet]. 2019 Jan [cited 2020 July 20];2(1):1-7. Available from:

https://ejurnalunsam.id/index.php/katalis/arti cle/view/1826/1371.

11. Ramli ME, Salleh RM. A potential of Telang tree (Clitoria ternatea) in human health. Food Research [Internet]. 2018 May [cited 2020 July 20];2:415-420. Available from: https://doi.org/10.26656/fr.2017.2(5).073.

12. Al-Snafi AE. Pharmacological importance of Clitoria ternatea-A review. IOSR Journal of Pharmacy [Internet]. 2016 March [cited 2020 July 20];6(3):68-83. Available from: http://iosrphr.org/papers/v6i3/G0636883.pdf

13. Gollen, B., Mehla, J. and Gupta, P., 2018. Clitoria ternatea Linn: A Herb with potential pharmacological activities: Future prospects as therapeutic Herbal Medicine. J Pharma Reports [Internet]. 2018 [cited 2020 July 20];3(1):1-8. Available from: https://www.longdom.org/openaccess/clitoria-ternatea-linn-a-herb-withpotential-pharmacological-activitiesfutureprospects-as-therapeutic-herbalmedicine.pdf.

14. Suganda T, Adhi SR. Uji pendahuluan efek fungisida bunga Kembang Telang (Clitoria ternatea L.) terhadap jamur Fusarium oxysporum $\mathrm{f}$. sp. cepae penyebab penyakit moler pada bawang merah. Agrikultura [Internet]. 2017 [cited 2020 July
20];28(3):136-140. Available from: https://doi.org/10.24198/agrikultura.v28i3.1 5746.

15. Sharmila G, Nikitha VS, Ilaiyarasi S, Dhivya K, Rajasekar V, Kumar NM, et al. Ultrasound assisted extraction of total phenolics from Cassia auriculata leaves and evaluation of its antioxidant activities. Industrial Crops and Products [Internet]. 2016 Jan [cited 2020 July 20];84:13-21. Available from: https://doi.org/10.1016/j.indcrop.2016.01.01 0 .

16. Purba EC. Kembang Telang (Clitoria ternatea L.): Pemanfaatan dan Bioaktivitas. EduMatSains [Internet]. 2020 Jan [cited $2020 \mathrm{Jul}$ 20];4(2):111-24. Available from: http://ejournal.uki.ac.id/index.php/edumatsai ns/article/view/1377.

17. Marpaung AM. Tinjauan manfaat bunga telang (clitoria ternatea 1.) bagi kesehatan manusia. JFFN [Internet]. 2020 Feb [cited 2020 July 20];1(2):63-5. Available from: https://journal.sgu.ac.id/jffn/index.php/jffn/a rticle/view/30.

18. Gunjan M, Ravindran M, Sengamalam R, Jana GK, Jha AK. Pharmacognostic and antidiabetic study of Clitoria ternatea. Phytomedicine [Internet]. 2010 [cited 2020 July 20];2(4):373-378. Available from: https://doi.org/10.5138/ijpm.2010.0975.018 5.02052.

19. Daisy P, Santosh K, Rajathi M. Antihyperglycemic and antihyperlipidemic effects of Clitoria ternatea Linn in alloxaninduced diabetic rats. African Journal of Microbiology Research [Internet]. 2008 Nov [cited 2020 July 20];3(5):287-291.

20. Nithianantham K, Shyamala M, Chen Y, Latha LY, Jothy SL, Sasidharan S. Hepatoprotective potential of Clitoria ternatea leaf extract against paracetamol induced damage in mice. Molecules [Internet]. 2011 Dec [cited 2020 July 20];16(12):10134-45. Available from: https://doi.org/10.3390/molecules16121013 4. 
21. Patschan D, Müller GA. Acute kidney injury. J Inj Violence Res. [Internet]. 2015 Jan [cited 2020 July 20];7(1):19-26. Available from: https://doi.org/10.5249/jivr.v7i1.604.

22. Gameiro J, Agapito Fonseca J, Jorge S, Lopes JA. Acute Kidney Injury Definition and Diagnosis: A Narrative Review. J Clin Med. [Internet]. 2018 Sep [cited 2020 July 20];7(10):307. Available from: https://doi.org/10.3390/jcm7100307.

23. Ostermann M, Chang RW. Acute kidney injury in the intensive care unit according to RIFLE. Crit Care Med. [Internet]. 2007 Aug [cited 2020 July 20];35(8):1837-43. Available from: https://doi.org/10.1097/01.CCM.000027704 1.13090.0A.

24. Makris K, Spanou L. Acute Kidney Injury: Definition, Pathophysiology and Clinical Phenotypes. Clin Biochem Rev. [Internet]. 2016 May [cited 2020 July 20];37(2):85-98. Available from: https://www.ncbi.nlm.nih.gov/pmc/articles/ PMC5198510/.

25. Brozovic A, Ambriović-Ristov A, Osmak M. The relationship between cisplatininduced reactive oxygen species, glutathione, and BCL-2 and resistance to cisplatin. Critical Reviews in Toxicology [Internet]. 2010 Jan [cited 2020 July 20];40(4):347-359. Available from: https://doi.org/10.3109/10408441003601836

26. Werdhasari A. Peran Antioksidan Bagi Kesehatan. Jurnal Biotek Medisiana Indonesia [Internet]. 2014 [cited 2020 July 20];3(2):59-68. Available from: https://media.neliti.com/media/publications/ 75830-ID-peran-antioksidan-bagi-

kesehatan.pdf.

27. Gupta GK, Chalal J, Bhatia M. Clitoria ternatea (L.): Old and new aspects. Journal of Pharmacy Research [Internet]. 2010 [cited 2020 July 20];3(11):2610-2614. Available

from: https://jprsolutions.info/files/final-file55851d33acdcd1.19607307.pdf.

28. Lakshan SAT, Jayanath NY, Mendis Abeysekera WPK, Abeysekera WKSM. A Commercial Potential Blue Pea (Clitoria ternatea L.) Flower Extract Incorporated Beverage Having Functional Properties. Evidence-Based Complementary and Alternative Medicine [Internet]. 2019 [cited 2020 July 20];1-13. Available from: https://doi.org/10.1155/2019/2916914

29. Somani R, Vadnal P, Deshmukh S. Hepatoprotective Activity of Clitoria Ternatea L. Leaves Against Carbon Tetrachloride Induced Hepatic Damage in Rats. Journal of Pharmacy Research [Internet]. 2011 [cited 2020 July 20];4(10):3540-3544. Available from: https://citeseerx.ist.psu.edu/viewdoc/downlo ad?doi=10.1.1.735.4277\&rep=rep1\&type $=p$ df.

30. Khaira K. Menangkal Radikal Bebas dengan Antioksidan. Jurnal Sainstek [Internet]. 2010 Dec [cited 2020 July 20];2:183-187. Available from: https://media.neliti.com/media/publications/ 129475-ID-menangkal-radikal-bebasdengan-anti-oksi.pdf.

31. Tonahi JMM, Nuryanti S, Suherman S. Antioksidan Dari Daun Sirih Merah (Piper Crocatum). Jurnal Akademika Kimia [Internet]. 2014 [cited 2020 July 20];3(3):158-164. Available from: http://jurnal.untad.ac.id/jurnal/index.php/JA K/article/view/7796.

32. Panche AN, Diwan AD, Chandra SR. Flavonoids: an overview. Journal of Nutritional Science [Internet]. 2016 [cited 2020 July 20];5(e47):1-15. Available from: https://doi.org/10.1017/jns.2016.41.

33. Akomolafe SF, Akinyemi AJ, Anadozie SO. Phenolic Acids (Gallic and Tannic Acids) Modulate Antioxidant Status and Cisplatin Induced Nephrotoxicity in Rats. International Scholarly Research Notices [Internet]. 2014 [cited 2020 July 20];1-8. 
Available from:

https://doi.org/10.1155/2014/984709.

34. Go J, Kim J-E, Koh E-K, Song S-H, Seung $\mathrm{J}-\mathrm{E}$, Park C-K, et al. Hepatotoxicity and nephrotoxicity of gallotannin-enriched extract isolated from Galla Rhois in ICR mice. Laboratory Animal Research [Internet]. 2015 [cited 2020 July 20];31(3):101. Available from: https://doi.org/10.5625/lar.2015.31.3.101. 